\title{
SPECIES COMPOSITION AND SPATIAL DISTRIBUTION OF A STREAM FISH ASSEMBLAGE IN THE EAST COAST OF BRAZIL: COMPARISON OF TWO FIELD STUDY METHODOLOGIES
}

\author{
UIEDA, V. S. and UIEDA, W. \\ Departamento de Zoologia, Instituto de Biociências, Universidade Estadual Paulista, C.P. 510, \\ CEP 18618-000, Botucatu, SP, Brazil \\ Correspondence to: Virginia Sanches Uieda, Departamento de Zoologia, Instituto de Biociências, \\ Universidade Estadual Paulista, C.P. 510, CEP 18618-000, Botucatu, SP, Brazil, e-mail: vsuieda@ibb.unesp.br \\ Received January 18, 2000 - Accepted April 26, 2000 - Distributed August 31, 2001
}

(With 1 figure)

\begin{abstract}
The species composition and spatial distribution of a fish assemblage were studied in three reaches of a river in the east coast of Brazil: a section of rapids (upper), another of water flowing on plain terrain (lowland) and the other of a mangrove environment. Two methods were employed with the purpose of estimating their effectiveness in naturalistic studies of tropical fish assemblages. One method consisted of underwater observations and the other was characterized by catches using gears such as fish traps, sieves and fishing rods. Both methods showed that their effectiveness is dependent upon the characteristics of the environment and the biology of the species. In areas of high water transparency and flow speed, rocky substrate and no submerged marginal vegetation (upper reach), the employment of the traditional gears was quite inefficient, despite the excellent conditions for underwater observations. In areas of clear water and high flow speed with abundant submerged marginal vegetation (lowland and mangrove), the gears were rather efficient yielding excellent results when coupled with direct observation methods. Since the abiotic characteristics of a stream change longitudinally, it is appropriate to employ different methods in the study of the ichthyofauna composition and distribution in order to reduce the constraints imposed by sampling methods in running waters.
\end{abstract}

Key words: coastal stream, spatial distribution, species composition, fish assemblage, underwater observation.

\section{RESUMO}

Composição e distribuição espacial de uma comunidade de peixes da costa leste do Brasil: comparação de duas metodologias de estudo de campo

A composição e a distribuição espacial de uma comunidade de peixes foram estudadas em três trechos de um rio na costa leste do Brasil: um trecho de corredeiras (superior), um trecho de planície (médio) e outro de mangue (inferior). Dois métodos foram empregados com o objetivo de estimar sua eficiência em estudos naturalísticos de comunidades de peixes tropicais. Um dos métodos consiste em observações subaquáticas e o outro é caracterizado por capturas com o emprego de apetrechos, como covos, peneiras, vara e anzol. Os dois métodos mostraram que sua eficiência depende das características do ambiente e da biologia das espécies. Em trechos com elevada transparência da água, correnteza forte, substrato rochoso e sem vegetação marginal submersa (trecho superior), o emprego de equipamentos tradicionais é relativamente ineficiente, apesar de oferecer excelentes condições para observação subaquática. Em trechos com elevada transparência da água, correnteza forte e vegetação marginal submersa abundante (planície e mangue), os apetrechos de coleta oferecem bons resultados, principalmente se acoplados ao método de observação subaquática. Se as características abióticas do rio se alteram longitudinalmente, nos estudos acerca da composição e da distribuição da ictiofauna é apropriado o emprego de diferentes métodos de estudo, a fim de reduzir as falhas impostas pelas metodologias de coleta empregadas em ambientes de água corrente.

Palavras-chave: riacho costeiro, distribuição espacial, composição de espécies, comunidade de peixes, observação subaquática. 


\section{INTRODUCTION}

In tropical regions, there is great fish abundance and high species richness. These species differ in habitat selection, diet, migration patterns, age structure and facility of capture (Welcomme, 1979). In lotic habitats, differences between pools and riffles cause species and fish size segregation. This habitat variability hampers the standardization and effectiveness of collection methods (Hynes, 1970). Studies carried out in the tropics have reported problems with the selectivity of fish capture methods. Such problems are related to fish size (Saul, 1975; Silva, 1982), capture of pelagic and benthic species (Silva, 1982), habitat heterogeneity (Garutti, 1988; Vianna, 1989), and behavioral differences (Vianna, 1989).

Underwater observation has been used as an important method in studies of Neotropical freshwater fish communities (Sazima, 1986; Sazima \& Caramaschi, 1989; Sazima \& Machado, 1990; Buck \& Sazima, 1995; Sabino \& Zuanon, 1998). In streams at the east coast of Brazil, Sabino \& Castro (1990) and São-Thiago (1990) have studied the fish fauna employing both traditional gear and underwater observation.

In the present study, the composition and spatial distribution of a tropical fish community were studied in three reaches of a coastal stream, in South-eastern Brazil, with different abiotic characteristics. A comparative analysis of the efficiency of underwater observation and collection with traditional gear was conducted.

\section{Study site}

The study was carried out in the Rio da Fazenda, located in the South-eastern Atlantic Coast of Brazil. Rio da Fazenda is part of the east basin drainage (a group of rivers that spring in the Serra do Mar and flow to the Atlantic Ocean) and is located between the cities of Ubatuba and Parati (23 $20^{\circ} \mathrm{S}$, $44^{\circ} 55^{\prime} \mathrm{W}$ ). Three reaches of this river (Fig. 1) were studied: an upper section with rapids ( $25 \mathrm{~m}$ width, 0.30 to $1.20 \mathrm{~m}$ depth), a lowland reach flowing over plain terrain (15 m width, 0.40 to $1.40 \mathrm{~m}$ depth) and a mangrove environment ( $15 \mathrm{~m}$ width, 0.30 to 1.50 $\mathrm{m}$ depth).

A strong current $\left(43 \mathrm{~cm} \mathrm{sec}^{-1}\right)$, low conductivity $\left(48 \mu \mathrm{S} \mathrm{cm}^{-1}\right)$, high dissolved oxygen $\left(9 \mathrm{mgO}_{2} \mathrm{~L}^{-1}\right)$ and water transparency, sandy and bedrock substrate, and no submerged marginal vegetation characterized the upper reach. The lowland reach had moderate current $\left(20 \mathrm{~cm} \mathrm{sec}^{-1}\right)$, low conductivity $\left(46 \mu \mathrm{S} \mathrm{cm}^{-1}\right)$, high dissolved oxygen $\left(9 \mathrm{mgO}_{2} \mathrm{~L}^{-1}\right)$ and water transparency, sandy and silt substrate, and abundant marginal vegetation (mainly Panicum sp., Graminae). The mangrove reach was characterized by a moderate current $\left(19 \mathrm{~cm} \mathrm{sec}^{-1}\right)$, high conductivity (355 and 649 $\mu \mathrm{S} \mathrm{cm} \mathrm{cm}^{-1}$ in low and high tide periods, respectively), low dissolved oxygen $\left(5 \mathrm{mgO}_{2} \mathrm{~L}^{-1}\right)$, high turbidity, sandy and silt substrate, and abundant marginal vegetation (mainly Hibiscus pernambucensis Arruda, Malphigiaceae and Scirpus californicus (Miy.) Stend, Ciperaceae).

\section{MATERIAL AND METHODS}

The composition and spatial distribution of the fish community of the Rio da Fazenda were sampled every two months, between July 1988 and June 1989. Sampling was carried out over a two day period per reach, totaling six consecutive days. At each reach, underwater observations (direct method) were performed on both days, but capture with traditional gears (indirect method) was done only on the second day. Fieldwork (observations and capture) was conducted from 8:00 to 16:00 h.

\section{Direct method}

The fish community was directly observed while snorkeling. Observation sessions lasted 15 to 120 minutes each (mean of 60 minutes), totaling approximately 30 hours of underwater observation per reach. During dives, visual census was used to determine species composition, fish length, and spatial distribution. Surveys were stratified both horizontally (pool, riffle, and riverside) and vertically (surface, midwater, and bottom). Observations at the mangrove reach were made during the low tide period, when the identification of fishes was possible because of the low depth and turbidity. The microhabitat current velocity was determined by using a Pitot tube (Brower \& Zar, 1984).

\section{Indirect method}

The indirect method consisted of catching with the use of traditional gears such as acrylic fish traps, sieves (mesh net $3 \mathrm{~mm}$ ), and fishing rods. The data obtained from the use of each tool included the species of the fish captured, fish total length, and place sampled (horizontal and vertical distribution). 

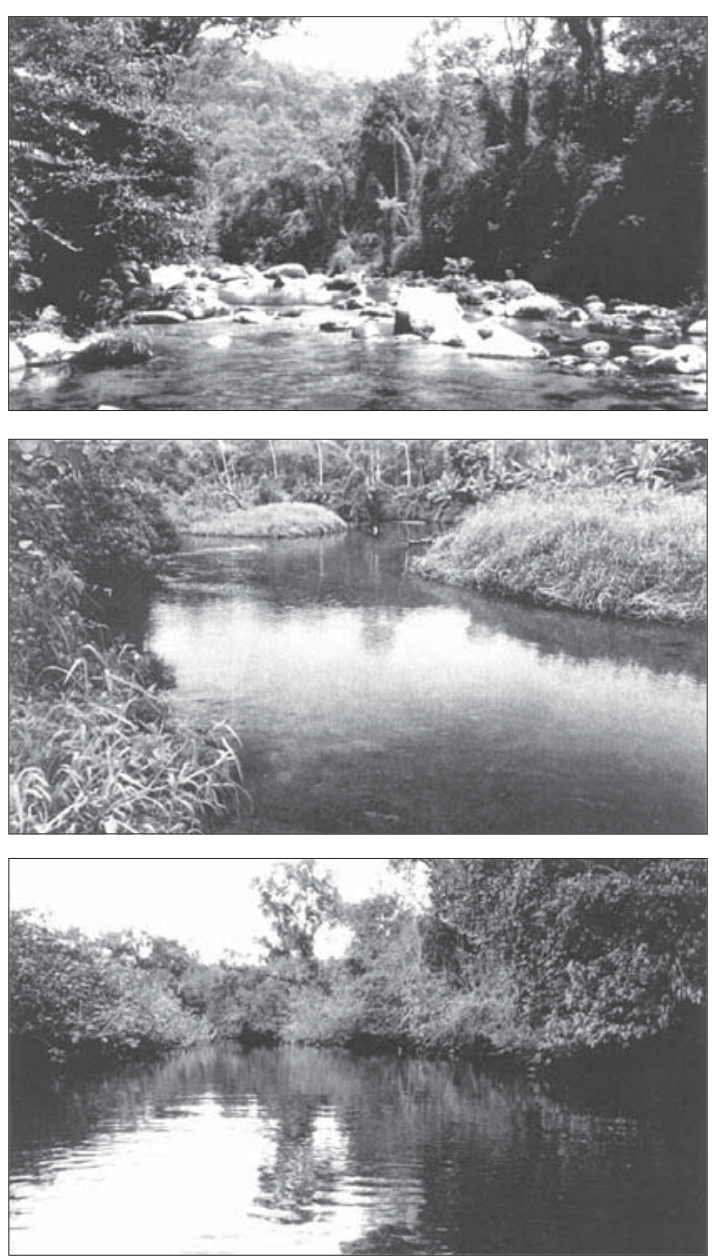

Fig. 1 - View of the three reaches of the Rio da Fazenda: upper, lowland and mangrove sections (from top to bottom).

Fish traps were placed for 30 minutes on the bottom, near the marginal vegetation, as much in pools as in riffles. Fishes captured were identified, measured, and released. Ten individuals per size class were fixed in $10 \%$ formalin. Sieves were also used at the marginal vegetation. Fishing rods were used in pools and riffles, and baits were positioned alternately near the surface and bottom.

All fishes captured with sieves and fishing rods were fixed. Seines were excluded from the samples after preliminary catching showed their low performance in habitats with rocky substrate, high current, and submerged branches. Collection with a small aquatic net (dipnet) combined with aquatic observation was used to sample the fish fauna that was observed but not captured with other equipment. The results of this collection were analyzed separately because they depended on a prior visual recognition of the fish.

\section{Statistical analysis}

The species presence/absence data obtained by the direct and indirect methods were compared by the Sorensen Similarity Coefficient (Brower \& Zar, 1984; Krebs, 1989). The Chi-square test was used to compare the frequency of individuals sampled per gear and per month. For the monthly analyses, June, July and September were grouped as "dry season", and November, January and March were grouped as "wet season" (based on data of Ubatuba city, presented in Sabino \& Castro, 1990). Differences in fish length among gears (selectivity) and months (seasonal tendency) were analyzed using ANOVA (SAS version 6.04). This analysis was applied only for the species with more than ten individuals sampled. The fish sampled with a dipnet were excluded from this analysis.

\section{RESULTS}

The fish species composition and spatial distribution data obtained emphasized the differences among reaches and methods. Twenty one fish species were surveyed in the three sections of the Rio da Fazenda using both direct and indirect methods combined (Table 1). The presence/absence data showed differences between the methods in relation to the species and reaches analyzed.

The comparison between presence/absence data of species observed and sampled with traditional gears (Table 1) resulted in a higher similarity coefficient in the lowland and mangrove reaches ( 0.82 and 0.83 , respectively) than in the upper reach (0.50). The visual recognition of the fish during underwater observation was important to determine the species composition of the upper reach. Similarity between the catching with dipnet and with traditional gears was higher in the lowland $(0.82)$ than in the upper and mangrove $(0.50$ and 0.66 , respectively) reaches. The use of dipnet following the visual recognition of the fish provided the best results at the upper section of the river. In contrast, gears such as sieves were more efficiently used at the mangrove reach.

\section{Direct method}

Upper reach - eight fish species were observed at this reach $(89 \%$ of the total surveyed by the two methods). 


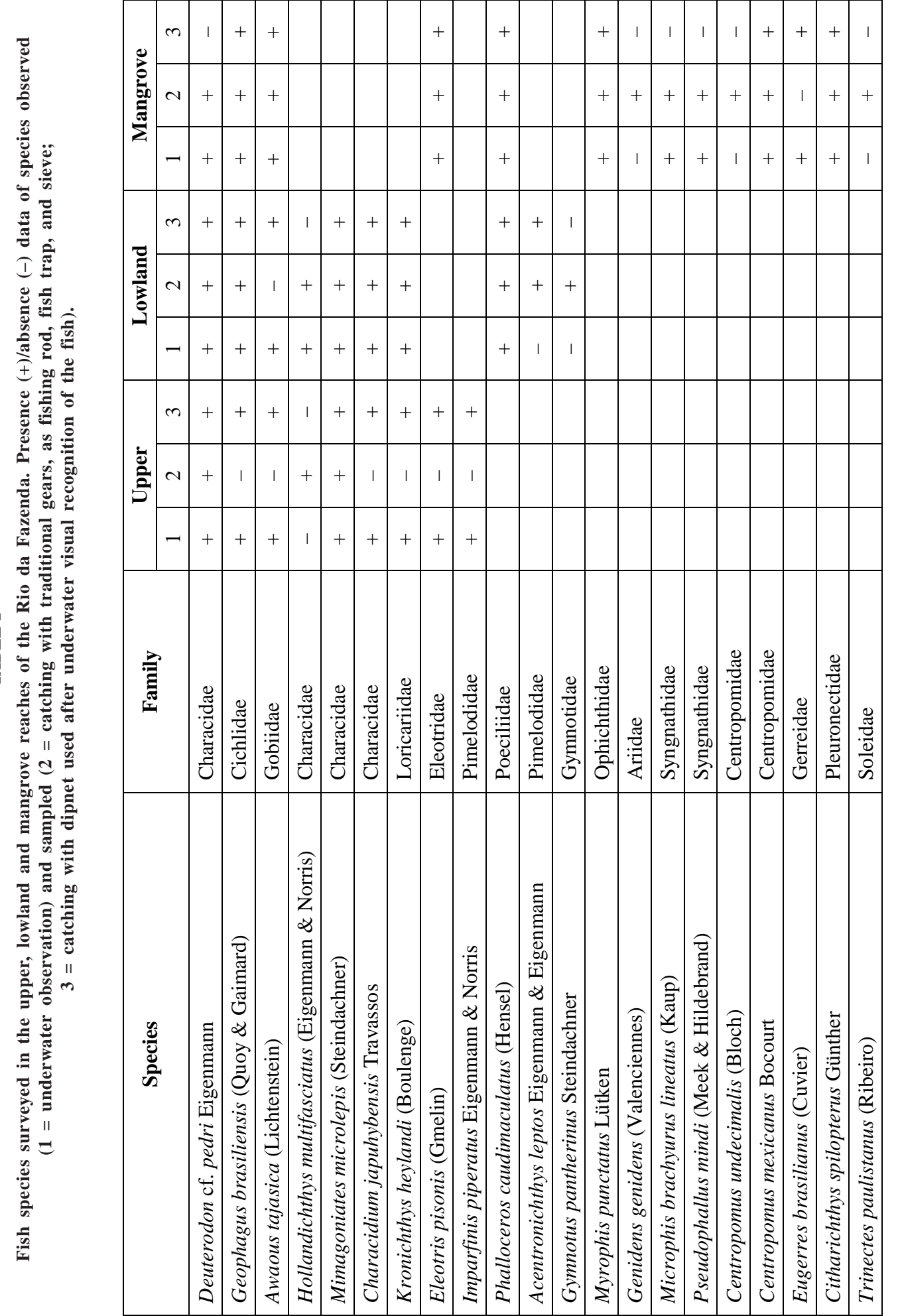


Only Hollandichthys multifasciatus was not observed, but it was sampled.

The spatial distribution of those species (Table 2) showed that they occur mainly near the bottom of pools and riffles. Deuterodon cf. pedri presented a broader distribution in the upper section. Differential distribution per size class of this species was observed - individuals with less than $60 \mathrm{~mm}$ TL were seen between the surface and midwater; fish bigger than $60 \mathrm{~mm}$ TL between midwater and the bottom, and fish with more than $100 \mathrm{~mm}$ TL mainly near the bottom. Mimagoniates microlepis was found associated with small individuals of $D$. cf. pedri at the pools. Kronichthys heylandi was found resting on submerged branches attached to rocks, in midwater of riffles. Five species were observed near or above the sandy and rocky substrate (Table 2). One of these species, Imparfinis piperatus, was observed mainly in holes formed by the rocks.

Lowland reach - eight fish species were observed at this reach $(80 \%$ of the total surveyed by both methods). These species (Table 2) occurred mainly among the submerged marginal vegetation and near the bottom. $D$. cf. pedri presented a broader distribution and the same differential distribution per size class. Two species, M. microlepis and Phalloceros caudimaculatus, were observed swimming along with small individuals of $D$. cf. pedri near the surface of shallow marginal pools. Most of the species found near the bottom were observed on the sandy substrate, except $K$. heylandi that was observed resting on submerged branches deposited on the bottom of pools or riffles.

Mangrove reach - eleven fish species were observed at the mangrove reach $(79 \%$ of the total surveyed by both methods). At this reach, most of the species were observed near the banks (Table 2) but in two different situations: either among the submerged marginal vegetation at midwater or near the muddy bottom under the vegetation. Only $D$. cf. pedri specimens longer than $50 \mathrm{~mm}$ were observed. Those fish swam in group of no more than 10 individuals, between midwater and bottom, under the marginal vegetation, with one or two juveniles of Centropomus mexicanus of similar size. Isolated $C$. mexicanus adults (> $150 \mathrm{~mm}$ TL) were observed swimming slowly around the submerged branches, between midwater and the bottom of a deep pool. Different size classes of Geophagus brasiliensis presented distribution similar to that of $C$. mexicanus. Small juveniles $(<30$ $\mathrm{mm}$ TL) of $G$. brasiliensis, Awaous tajasica, and $C$. mexicanus were observed in shallow marginal pools with muddy bottoms. Myrophis punctatus and Citharichthys spilopterus were also found in these places, but frequently with their bodies partially burrowed in the mud. A. tajasica adults were the only fish observed in the middle of the river, swimming near the sandy bottom of this stretch.

\section{Indirect method}

Number of species and individuals per tool and per month - the total number of species and individuals differed according to the used gears and reaches observed (Table 3). At the upper reach, the higher number of species was collected with a dipnet and the higher number of individuals was collected with fishing rod. At lowland, a high number of species was sampled with dipnet and sieve, whereas fish trap and sieve captured the higher percentage of individuals. The sieve was the most efficient tool at the mangrove reach. It allowed the catching of the most species and the higher percentage of the individuals. In contrast, the reaches showed similar seasonal trends, with a significantly high number of individuals collected at the wet season (Table 4).

Size of the fish per tool and per month $-\mathrm{a}$ selectivity of tools in relation to the size of the fish sampled was also evident (Table 5), whereas a monthly variation was not so apparent and well defined (Table 6). The effect of the gear employed on fish size was significant in all the cases analyzed (Table 7). For D. cf. pedri and G. brasiliensis, the larger fish were sampled with fishing rod and the smaller ones with sieve. For $H$. multifasciatus, the fish sampled with fishing rod and fish trap were larger than those sampled with sieve. For $M$. $m i$ crolepis, fish trap enabled the collection of fish larger than those captured with sieve. Although a significant monthly variation was observed in most of the species of the lowland reach, a seasonal difference in size classes was evident only in the cases of $D$. cf. pedri and $K$. heylandi, in which small fish predominated in the dry season samples.

\section{DISCUSSION}

Representative fish sampling is hard to obtain in streams (Hynes, 1970; Uieda \& Castro, 1999). Most usual methodologies are difficult or impos- 
sible to be applied in this kind of habitat (Uieda, 1984). Characteristics such as high water transparency, rocky bottom, high amount of submerged plant material, and high current reduce the efficiency of some tools, mainly seines. Vianna (1989), Sabino \& Castro (1990) and São-Thiago (1990) reported difficulties in performing studies of fish in lotic habitats due to these abiotic characteristics. Sabino \& Castro (1990) and São-Thiago (1990) used underwater observation as a methodology coupled to the use of habitual tools. Direct observation and sampling with dipnets during snorkeling allowed Sabino \& Castro (1990) to study the feeding behavior, spatial and temporal distribution of stream fishes. For São-Thiago (1990), underwater observation provided additional information about the composition, frequency and abundance of fish species that were difficult to study using traditional gears alone. In the present study, the efficiency of the direct and indirect methods, used in determi- ning the composition and distribution of fish species, was influenced by the characteristics of the three reaches.

At Rio da Fazenda, the fish species distribution determined by underwater observation might be related to water current and presence of shelter. The fact that most species occurred near the bottom of the upper reach might be related with the low water current at this microhabitat and to the shelter availability provided by the rocks. The absence of submerged marginal vegetation probably determined the low occurrence of species in midwater and at the surface, where the water current is strong. $D$. cf. pedri and M. microlepis juveniles swam near the surface but only in marginal shallow pools.

The abundance of submerged marginal vegetation caused more species to be present in the midwater of the lowland reach. Near the bottom, there was also the advantage of low water current and sheltering among plant detritus.

TABLE 2

Spatial distribution (water column position and horizontal position) of the fish species sampled at the three reaches of the Rio da Fazenda, determined by underwater observation (current $=\mathrm{cm}_{\mathbf{s e c}} \mathrm{s}^{-1}$ ). Species abbreviations: Dpe = D. cf. pedri, Gbr = G. brasiliensis, Ata = A. tajasica, Hmu = H. multifasciatus, Mmi $=$ M. microlepis, $\mathrm{Cja}=C$. japuhybensis, $\mathrm{Khe}=K$. heylandi, Epi $=$ E. pisonis, $\mathbf{I p i}=I$. piperatus, $\mathrm{Pca}=P$. caudimaculatus, $\mathrm{Mpu}=$ M. punctatus, $\mathrm{Mli}=$ M. brachyurus lineatus, $\mathrm{Cme}=$ C. mexicanus, Csp $=$ C. spilopterus.

\begin{tabular}{|c|c|c|c|c|c|c|}
\hline \multirow[b]{3}{*}{$\begin{array}{c}\text { Water } \\
\text { column } \\
\text { position }\end{array}$} & \multicolumn{6}{|c|}{ Horizontal position } \\
\hline & \multicolumn{2}{|c|}{ Upper reach } & \multicolumn{2}{|c|}{ Lowland reach } & \multicolumn{2}{|c|}{ Mangrove reach } \\
\hline & Pool & Riffle & Bank & Open water & Bank & Open water \\
\hline \multirow{4}{*}{ Surface } & Dpe & & Dpe & & & \\
\hline & $\mathrm{Mmi}$ & & $\mathrm{Mmi}$ & & & \\
\hline & & & Pca & & & \\
\hline & $(30.82)$ & $(67.56)$ & $(15.21)$ & $(36.94)$ & $(19.50)$ & $(34.83)$ \\
\hline \multirow{6}{*}{ Midwater } & Dpe & Dpe & Dpe & Dpe & Dpe & \\
\hline & & Khe & Gbr & & Gbr & \\
\hline & & & $\mathrm{Hmu}$ & & Pca & \\
\hline & & & $\mathrm{Mmi}$ & & Epi & \\
\hline & & & Khe & & Mli & \\
\hline & & & Pca & & Cme & \\
\hline (current) & $(34.56)$ & $(52.49)$ & $(21.57)$ & $(35.70)$ & $(22.78)$ & $(34.83)$ \\
\hline \multirow{7}{*}{ Bottom } & Dpe & Dpe & Dpe & Dpe & Gbr & Ata \\
\hline & Gbr & Gbr & Gbr & Ata & Ata & \\
\hline & $\mathrm{Cja}$ & $\mathrm{Cja}$ & Ata & $\mathrm{Cja}$ & $\mathrm{Mpu}$ & \\
\hline & Ata & Ata & Cja & Khe & Cme & \\
\hline & Epi & Epi & Khe & & Csp & \\
\hline & Ipi & Ipi & & & & \\
\hline & $(22.13)$ & $(33.20)$ & $(14.07)$ & $(15.17)$ & $(16.47)$ & $(28.30)$ \\
\hline
\end{tabular}


TABLE 3

Number of individuals ( $\mathrm{N}$ and \%) of the fish species sampled per gear in the three reaches of Rio da Fazenda. Chi-Square $\left(x^{2}\right)$ was performed on data for the total of fishes sampled per tool $(* *=1 \%$ of significance).

\begin{tabular}{|c|c|c|c|c|c|c|c|c|}
\hline \multirow{2}{*}{ Species } & \multicolumn{2}{|c|}{ Fishing rod } & \multicolumn{2}{|c|}{ Fish trap } & \multicolumn{2}{|c|}{ Sieve } & \multicolumn{2}{|c|}{ Dipnet } \\
\hline & $\mathbf{N}$ & $\%$ & $\mathbf{N}$ & $\%$ & $\mathbf{N}$ & $\%$ & $\mathbf{N}$ & $\%$ \\
\hline D. cf. pedri & 189 & 49.1 & 103 & 26.8 & 72 & 18.7 & 21 & 5.4 \\
\hline G. brasiliensis & - & - & - & - & - & - & 25 & 100 \\
\hline A. tajasica & - & - & - & - & - & - & 15 & 100 \\
\hline H. multifasciatus & - & - & - & - & 1 & 100 & - & - \\
\hline M. microlepis & - & - & 3 & 21.4 & 7 & 50 & 4 & 28.6 \\
\hline C. japuhybensis & - & - & - & - & - & - & 6 & 100 \\
\hline K. heylandi & - & - & - & - & - & - & 13 & 100 \\
\hline E. pisonis & - & - & - & - & - & - & 1 & 100 \\
\hline I. piperatus & - & - & - & - & - & - & 4 & 100 \\
\hline $\begin{array}{l}\text { Total upper } \\
\left(x^{2}=64.25 * *\right)\end{array}$ & 189 & 40.7 & 106 & 22.8 & 80 & 17.2 & 89 & 19.2 \\
\hline D. cf. pedri & 182 & 16.3 & 662 & 59.4 & 256 & 23 & 15 & 1.3 \\
\hline G. brasiliensis & 63 & 56.8 & 2 & 1.8 & 34 & 30.6 & 12 & 10.8 \\
\hline A. tajasica & - & - & - & - & - & - & 38 & 100 \\
\hline H. multifasciatus & 15 & 41.7 & 7 & 19.4 & 14 & 38.9 & - & - \\
\hline M. microlepis & - & - & 24 & 25.3 & 51 & 53.7 & 20 & 21 \\
\hline C. japuhybensis & - & - & - & - & 5 & 15.1 & 28 & 84.8 \\
\hline K. heylandi & - & - & - & - & 108 & 95.6 & 5 & 4.4 \\
\hline P. caudimaculatus & - & - & 1 & 1 & 78 & 75.7 & 24 & 23.3 \\
\hline A. leptos & - & - & - & - & 7 & 87.5 & 1 & 12.5 \\
\hline G. pantherinus & - & - & - & - & 2 & 100 & - & - \\
\hline $\begin{array}{l}\text { Total lowland } \\
\left(x^{2}=475.35 * *\right)\end{array}$ & 260 & 15.7 & 696 & 42.1 & 555 & 33.6 & 143 & 8.6 \\
\hline D. cf. pedri & 79 & 58.5 & 55 & 40.7 & 1 & 0,7 & - & - \\
\hline G. brasiliensis & 19 & 42.2 & - & - & 25 & 55.6 & 1 & 2.2 \\
\hline A. tajasica & 1 & 2.9 & - & - & 15 & 42.9 & 19 & 54.3 \\
\hline P. caudimaculatus & - & - & - & - & 13 & 92.9 & 1 & 7.1 \\
\hline E. pisonis & - & - & - & - & 85 & 98.8 & 1 & 1.2 \\
\hline M. punctatus & - & - & - & - & 1 & 16.7 & 5 & 83.3 \\
\hline G. genidens & 13 & 100 & - & - & - & - & - & - \\
\hline M. brachyurus & - & - & - & - & 26 & 100 & - & - \\
\hline P. mindi & - & - & - & - & 17 & 100 & - & - \\
\hline C. undecimalis & 1 & 100 & - & - & - & - & - & - \\
\hline C. mexicanus & 4 & 26.7 & - & - & 7 & 46.7 & 4 & 26.7 \\
\hline E. brasilianus & - & - & - & - & - & - & 6 & 100 \\
\hline C. spilopterus & - & - & - & - & 1 & 50 & 1 & 50 \\
\hline T. paulistanus & - & - & - & - & 5 & 100 & - & - \\
\hline $\begin{array}{l}\text { Total mangrove } \\
\left(\mathrm{x}^{2}=151.38 * *\right)\end{array}$ & 117 & 28.8 & 55 & 13.5 & 196 & 48.3 & 38 & 9.3 \\
\hline
\end{tabular}


TABLE 4

Number of individuals ( $N$ and $\%$ ) of the fish species sampled per season (dry = June, July and September; wet $=$ November, January and March). Chi-Square $\left(\mathrm{x}^{2}\right)$ was performed on data for the total of fishes sampled per $\operatorname{season}(* *=1 \%$ of significance $)$.

\begin{tabular}{|c|c|c|c|c|}
\hline \multirow{2}{*}{ Species } & \multicolumn{2}{|c|}{ Dry } & \multicolumn{2}{|c|}{ Wet } \\
\hline & $\mathbf{N}$ & $\%$ & $\mathbf{N}$ & $\%$ \\
\hline D. cf. pedri & 166 & 43.2 & 219 & 56.9 \\
\hline G. brasiliensis & 1 & 4 & 24 & 96 \\
\hline A. tajasica & 3 & 20 & 12 & 80 \\
\hline H. multifasciatus & - & - & 1 & 100 \\
\hline M. microlepis & 4 & 28.6 & 10 & 71.4 \\
\hline C. japuhybensis & 2 & 33.3 & 4 & 66.7 \\
\hline K. heylandi & 1 & 7.7 & 12 & 92.3 \\
\hline E. pisonis & - & - & 1 & 100 \\
\hline I. piperatus & - & - & 4 & 100 \\
\hline $\begin{array}{l}\text { Total upper } \\
\left(x^{2}=25.6^{* *}\right)\end{array}$ & 177 & 38.1 & 287 & 61.9 \\
\hline D. cf. pedri & 515 & 46.2 & 600 & 53.8 \\
\hline G. brasiliensis & 28 & 25.2 & 83 & 74.8 \\
\hline A. tajasica & 10 & 26.3 & 28 & 73.7 \\
\hline H. multifasciatus & 22 & 61.1 & 14 & 38.9 \\
\hline M. microlepis & 52 & 54.7 & 43 & 42.3 \\
\hline C. japuhybensis & 16 & 48.5 & 17 & 51.5 \\
\hline K. heylandi & 67 & 59.3 & 46 & 40.7 \\
\hline P. caudimaculatus & 25 & 24.3 & 78 & 75.7 \\
\hline A. leptos & 5 & 62.5 & 3 & 37.5 \\
\hline G. pantherinus & 1 & 50 & 1 & 50 \\
\hline $\begin{array}{l}\text { Total lowland } \\
\left(x^{2}=17.68 * *\right)\end{array}$ & 741 & 44.8 & 913 & 55.2 \\
\hline D. cf. pedri & 16 & 11.9 & 119 & 88.1 \\
\hline G. brasiliensis & 6 & 13.3 & 39 & 86.7 \\
\hline A. tajasica & 11 & 31.4 & 24 & 68.6 \\
\hline P. caudimaculatus & 11 & 78.6 & 3 & 21.4 \\
\hline E. pisonis & 20 & 23.2 & 66 & 76.8 \\
\hline M. punctatus & - & - & 6 & 100 \\
\hline G. genidens & 3 & 23.1 & 10 & 76.9 \\
\hline M. brachyurus & 10 & 38.5 & 16 & 61.5 \\
\hline P. mindi & 3 & 17.6 & 14 & 82.3 \\
\hline C. undecimalis & - & - & 1 & 100 \\
\hline C. mexicanus & 7 & 46.7 & 8 & 53.3 \\
\hline E. brasilianus & - & - & 6 & 100 \\
\hline C. spilopterus & 1 & 50 & 1 & 50 \\
\hline T. paulistanus & 5 & 100 & - & - \\
\hline $\begin{array}{l}\text { Total mangrove } \\
\left(\mathrm{x}^{2}=118.14^{* *}\right)\end{array}$ & 93 & 22.9 & 313 & 77.1 \\
\hline
\end{tabular}


TABLE 5

Size (mean and standard deviation of the TL in $\mathrm{mm}$ ) of the fish species sampled in the three reaches of Rio da Fazenda (excluding dipnet samples).

\begin{tabular}{|c|c|c|c|}
\hline Species & Fishing rod & Fish trap & Sieve \\
\hline \multicolumn{4}{|l|}{ Upper reach } \\
\hline D. cf. pedri & $80.3 \pm 13.3$ & $67.2 \pm 17.4$ & $41.5 \pm 8.2$ \\
\hline H. multifasciatus & - & - & 105 \\
\hline M. microlepis & - & $50.3 \pm 9.4$ & $47.3 \pm 6.2$ \\
\hline \multicolumn{4}{|l|}{ Lowland reach } \\
\hline D. cf.pedri & $83.9 \pm 14.8$ & $77.9 \pm 16.6$ & $35.5 \pm 11.8$ \\
\hline G. brasiliensis & $91.4 \pm 19.5$ & $38 \pm 4.2$ & $33.9 \pm 17$ \\
\hline H. multifasciatus & $91.3 \pm 9.4$ & $90.9 \pm 8.1$ & $66.5 \pm 16.8$ \\
\hline M. microlepis & - & $44.8 \pm 6.1$ & $36.4 \pm 6.5$ \\
\hline C. japuhybensis & - & - & $27.6 \pm 1.1$ \\
\hline K. heylandi & - & - & $62.1 \pm 23.1$ \\
\hline$P$. caudimaculatus & - & 37 & $26.2 \pm 8.8$ \\
\hline A. leptos & - & - & $57.6 \pm 15.3$ \\
\hline G. pantherinus & - & - & $200 \pm 42.4$ \\
\hline \multicolumn{4}{|l|}{ Mangrove reach } \\
\hline D. cf. pedri & $102.7 \pm 15.8$ & $81.9 \pm 17.9$ & 56 \\
\hline G. brasiliensis & $128.9 \pm 28.6$ & - & $28.4 \pm 15.6$ \\
\hline A. tajasica & 126 & - & $36.9 \pm 6.1$ \\
\hline P. caudimaculatus & - & - & $31.2 \pm 7.4$ \\
\hline E. pisonis & - & - & $48.4 \pm 13.6$ \\
\hline M. punctatus & - & - & 106 \\
\hline G. genidens & $196.1 \pm 26.1$ & - & - \\
\hline M. brachyurus & - & - & $113.8 \pm 13.4$ \\
\hline$P$. mindi & - & - & $82.8 \pm 13.5$ \\
\hline C. undecimalis & 285 & - & - \\
\hline C. mexicanus & $221.2 \pm 62.1$ & - & $23 \pm 2.9$ \\
\hline C. spilopterus & - & - & 60 \\
\hline T. paulistanus & - & - & $25.6 \pm 7.8$ \\
\hline
\end{tabular}

The different microhabitats analyzed at the mangrove reach presented similar current measures. The fish distribution at this reach seemed to be more closely related to the presence of abundant submerged marginal vegetation that provides shelter and food for the fish.

Caramaschi (1986), Costa (1987) and Teixeira (1989) pointed to the importance of the role played by the marginal vegetation in the distribution of fish in tropical streams.
Caramaschi (1986) suggested that fish species could use this vegetation as a temporary or permanent shelter and foraging place.

The methods used in previous studies on tropical fish were selective and dependent on the distribution of the species. On the other hand, this distribution is related with fish size and behavior. In our study, fish behavior and habitat characteristics were important to determine the degree of selectivity of the sampling tools. 
TABLE 6

Size (mean and standard deviation of TL in $\mathrm{mm}$ ) of the fish species sampled, over the period of one year, in three reaches of Rio da Fazenda.

\begin{tabular}{|c|c|c|c|c|c|c|}
\hline Species & June & July & September & November & January & March \\
\hline \multicolumn{7}{|l|}{ Upper reach } \\
\hline D. cf. pedri & $67 \pm 20.8$ & $67.8 \pm 18.7$ & $61.2 \pm 21.6$ & $79.2 \pm 13.5$ & $67.9 \pm 17.6$ & $62.6 \pm 23.8$ \\
\hline G. brasiliensis & 63 & - & - & - & $87.3 \pm 17.8$ & $91.6 \pm 21.9$ \\
\hline A. tajasica & $75 \pm 24.6$ & - & - & - & $68.8 \pm 14.8$ & $80.8 \pm 24.7$ \\
\hline H. multifasciatus & - & - & - & - & - & 105 \\
\hline M. microlepis & $55.5 \pm 7.8$ & $45 \pm 2.8$ & - & - & $45.2 \pm 2.1$ & $47.3 \pm 6.4$ \\
\hline C. japuhybensis & $32.5 \pm 5$ & - & - & - & $41 \pm 4.2$ & $35.5 \pm 5$ \\
\hline K. heylandi & 71 & - & - & $53 \pm 14.1$ & $69.3 \pm 1.5$ & $72 \pm 18.5$ \\
\hline E. pisonis & - & - & - & - & - & 160 \\
\hline I. piperatus & - & - & - & 178 & $65 \pm 29.7$ & 205 \\
\hline \multicolumn{7}{|l|}{ Lowland reach } \\
\hline D. cf. Pedri & $67.5 \pm 17.2$ & $60.3 \pm 26.1$ & $60.1 \pm 25.5$ & $71.8 \pm 24.3$ & $71.6 \pm 21.2$ & $77.6 \pm 23.4$ \\
\hline G. brasiliensis & $83.4 \pm 32.6$ & $48.3 \pm 23.5$ & $45.8 \pm 28.9$ & $65.4 \pm 28.9$ & $88.6 \pm 41.1$ & $71.1 \pm 35.4$ \\
\hline A. tajasica & $87 \pm 18.9$ & - & - & $111 \pm 20.7$ & $92.2 \pm 19.8$ & $80.4 \pm 17.7$ \\
\hline H. multifasciatus & $93.8 \pm 8.9$ & $58.5 \pm 9.2$ & $83.2 \pm 15$ & $72.6 \pm 17.7$ & $75.5 \pm 11.4$ & $72.6 \pm 25$ \\
\hline M. microlepis & $43.4 \pm 6.8$ & $34.5 \pm 7.4$ & $39.4 \pm 6.8$ & $44.3 \pm 6.4$ & $41.5 \pm 6.4$ & $39.6 \pm 5.8$ \\
\hline C. japuhybensis & $31.6 \pm 5.3$ & - & - & $41.7 \pm 0.6$ & $37.6 \pm 7.9$ & $31.3 \pm 4.7$ \\
\hline K. heylandi & $49.2 \pm 31$ & $57.8 \pm 22$ & $60.5 \pm 18.8$ & $69.5 \pm 23.5$ & $66.9 \pm 20$ & $83.6 \pm 17.7$ \\
\hline P. caudimaculatus & $29.5 \pm 7.7$ & $33.8 \pm 6.3$ & $35.2 \pm 2.1$ & $27.8 \pm 8.8$ & $25.8 \pm 11.3$ & $35.7 \pm 12.6$ \\
\hline A. leptos & - & $61.5 \pm 20.5$ & $45.3 \pm 5.5$ & $67 \pm 9.5$ & - & - \\
\hline G. pantherinus & - & - & 230 & - & 170 & - \\
\hline \multicolumn{7}{|l|}{ Mangrove reach } \\
\hline D. cf. pedri & $100 \pm 10$ & $106.7 \pm 8.2$ & 100 & $93.9 \pm 17$ & $94.9 \pm 27.8$ & $90.9 \pm 16.8$ \\
\hline G. brasiliensis & $48.5 \pm 30.2$ & $34 \pm 1.4$ & - & $116.2 \pm 42.6$ & $72.9 \pm 59.9$ & $65.4 \pm 53$ \\
\hline A. tajasica & $38 \pm 2.8$ & $37.5 \pm 9.2$ & $36.9 \pm 6.8$ & $39.7 \pm 7$ & $52.3 \pm 36.6$ & $76.9 \pm 25.4$ \\
\hline P. caudimaculatus & $24.3 \pm 6$ & 30 & $33.3 \pm 9.6$ & $27 \pm 1.4$ & 34 & - \\
\hline E. pisonis & $44.7 \pm 6.1$ & $37.8 \pm 16.4$ & $41.3 \pm 11.5$ & $44.4 \pm 10.6$ & $51.3 \pm 13.1$ & $56.5 \pm 13.3$ \\
\hline M. punctatus & - & - & - & $120.2 \pm 9.1$ & 106 & 118 \\
\hline G. genidens & $210 \pm 42.7$ & - & - & - & - & $191.9 \pm 20.5$ \\
\hline M.brachyurus & $114.3 \pm 6.8$ & - & 152 & $109.8 \pm 11.7$ & $115.3 \pm 18.1$ & $110.2 \pm 13.3$ \\
\hline P. mindi & 70 & 82 & 87 & $91.9 \pm 7.1$ & $81.3 \pm 16$ & $63 \pm 4.6$ \\
\hline C. undecimalis & - & - & - & - & - & 285 \\
\hline C. mexicanus & 25 & $21.7 \pm 3.5$ & $23.7 \pm 2.5$ & 42 & 295 & $135.2 \pm 90.4$ \\
\hline E. brasilianus & - & - & - & - & - & $39.3 \pm 9.8$ \\
\hline C. spilopterus & - & - & 60 & - & - & 96 \\
\hline T. paulistanus & 22 & 25 & $27 \pm 10.5$ & - & - & - \\
\hline
\end{tabular}

Most species observed at the upper reach were difficult to collect because they look for shelter near or among the rocks in the bottom. This behavior, added to the high water transparency and absence of submerged marginal vegetation, represented a problem for the use of the usual methodology (indirect method). At the upper reach, underwater obser- vation and sampling with a dipnet were essential for the study of the composition and distribution of the fish community.

On the other hand, at the lowland and mangrove reaches the higher efficiency of fish trap and sieve may be related to the behavior and distribution of most species, searching for shelter and 
food at the marginal vegetation. The dipnet was also efficient at the lowland reach where there was high water transparency.

Silva (1982) concluded that the data on fish abundance as well as the biological data obtained in a study of an estuarine fish community were not consistent because the methods used were not appropriate to the sampling of juveniles, and pelagic and benthic species. Allen et al. (1992) also worked on an estuarine fish community and verified that the efficiency of seine nets depended on fish length and behavior.

Habitat characteristics also influence the efficiency of sampling. Streams with high water transparency and current that have submerged plant detritus restrict the use of some equipment (Vianna, 1989; Sabino \& Castro, 1990; São-Thiago, 1990). Moreover, some abiotic characteristics can present seasonal variations.

During the dry season, pools can become small or disappear and cause some problems to the standardization of sampling methodology (Garutti, 1988; São-Thiago, 1990).
Although the water level and turbidity were higher during the wet season in the Rio da Fazenda, a larger number of individuals were obtained over this period. An increase in fish population may occur due to the addition of more species or juveniles during the wet season. Caramaschi (1986) and Garutti (1988) reported a high number of species and a habitat expansion in neotropical streams during the wet season. At both the upper and mangrove reaches of Rio da Fazenda, the increase in the number of individuals during the wet season is likely to be related to an increase in the number of species. A recruitment of juveniles does not explain it because the monthly variation in fish length was not significant in those reaches.

On the other hand, an increase in the number of species was not observed at the lowland reach, although the monthly variation in fish length was significant. Habitat expansion also occurred at both the lowland and mangrove reaches, where an increase in the water level during the wet season caused an increase in the amount of marginal submerged vegetation.

TABLE 7

Probabilities for ANOVAs testing for the gears (except dipnet) and months effects over the length of the fishes. The analysis was performed only for the most abundant species of each reach.

\begin{tabular}{|c|c|c|}
\hline \multirow{2}{*}{ Species analyzed } & \multicolumn{2}{|c|}{ Source of variation } \\
\hline & Gear & Month \\
\hline \multicolumn{3}{|l|}{ Upper reach } \\
\hline Total of species & 0.000 & 0.066 \\
\hline D. cf. pedri & 0.000 & - \\
\hline M. microlepis & 0.553 & - \\
\hline \multicolumn{3}{|l|}{ Lowland reach } \\
\hline Total of species & 0.000 & 0.000 \\
\hline D. cf. pedri & 0.000 & 0.000 \\
\hline G. brasiliensis & 0.000 & 0.069 \\
\hline H. multifasciatus & 0.000 & 0.014 \\
\hline M. microlepis & 0.000 & 0.000 \\
\hline K. heylandi & - & 0.026 \\
\hline P. caudimaculatus & - & 0.000 \\
\hline \multicolumn{3}{|l|}{ Mangrove reach } \\
\hline Total of species & 0.000 & 0.079 \\
\hline D. cf. pedri & 0.000 & - \\
\hline G. brasiliensis & 0.000 & - \\
\hline
\end{tabular}


The relation between sample selectivity and fish length (Saul, 1975; Silva, 1982; Allen et al., 1992) was also observed in the present work. Fishing rod and fish trap were selective for large fishes and sieve for small fishes.

The efficiency of sampling methods depends on habitat characteristics and biology of species. The utilization of traditional methodology coupled with underwater observation was essential for the quality of the results about species composition and spatial distribution of this stream fish assemblage.

Every river has different characteristics from the upstream to downstream. Thus, in studies on the longitudinal composition and distribution of the fish fauna it is important to use different methods in order to obtain the most complete fish diversity index. Obviously it is not appropriate to destroy a community with an extensive collection. Good sense is welcome when the type and extension of the sampling is determined. Diving and direct observations cause very little impact (Sabino \& Zuanon, 1998) and need to be considered as a good choice in habitats where this methodology can be applied.

Acknowledgments - We are grateful to Neuza N. Uieda for the field assistance, to Instituto Florestal for the permission to use the park, to the servants of Parque Estadual da Serra do Mar for their help and assistance during the study, and to Eleonora Trajano for the review of the manuscript. Fundunesp (Proc. 288/88) and Capes (PICD 89/91) funded this study.

\section{REFERENCES}

ALLEN, D. M., SERVICE, S. K. \& MATTHEWS, M. V. O., 1992, Factors influencing the collection efficiency of estuarine fishes. Trans. Amer. Fish. Soc., 121: 234-244.

BROWER, J. E. \& ZAR, J. H., 1984, Field and laboratory methods for general ecology. $2^{\text {nd }}$ ed., Wm. C. Brown, Dubuque, 226p.

BUCK, S. \& SAZIMA, I., 1995, An assemblage of mailed catfishes (Loricariidae) in southeastern Brazil: distribution, activity, and feeding. Ichthyol. Explor. Freshwaters, 6: 325-332.

CARAMASCHI, E. P., 1986, Distribuição da ictiofauna de riachos das bacias do Tietê e do Paranapanema, junto ao divisor de águas (Botucatu, SP). Ph.D. Thesis, Universidade Federal de São Carlos, São Carlos, Brazil, 245p.

COSTA, W. J. E. M., 1987, Feeding habits of a fish community in a tropical coastal stream, Rio Mato Grosso, Brazil. Stud. Neotrop. Fauna Environ., 22: 145-153.
GARUTTI, V., 1988, Distribuição longitudinal da ictiofauna de um córrego na região noroeste do Estado de São Paulo, Bacia do Rio Paraná. Rev. Brasil. Biol., 48: 747-759.

HYNES, H. B. N., 1970, The ecology of running waters. University of Toronto, Canada, 555p.

KREBS, C. J., 1989, Ecological methodology. Harper \& Row, New York, 652p.

SABINO, J. \& CASTRO, R. M. C., 1990, Alimentação, período de atividade e distribuição espacial dos peixes de um riacho da Floresta Atlântica (Sudeste do Brasil). Rev. Brasil. Biol., 50: 23-36.

SABINO, J. \& ZUANON, J., 1998, A stream fish assemblage in Central Amazonia: distribution, activity patterns and feeding behavior. Ichthyol. Explor. Freshwaters, 8: 201-210.

SÃO-THIAGO, H., 1990, Composição e distribuição longitudinal da ictiofauna do Rio Parati-Mirim (RJ) e período reprodutivo das principais espécies. Master Thesis, Museu Nacional e Universidade Federal do Rio de Janeiro, Rio de Janeiro, Brazil, 165p.

SAUL, W. G., 1975, An ecological study of fishes at a site in upper Amazonian Ecuador. Proc. Acad. Nat. Sc. Philad., 127: 93-134.

SAZIMA, I., 1986, Similarities in feeding behaviour between some marine and freshwater fishes in two tropical communities. J. Fish Biol., 29: 53-65.

SAZIMA, I. \& CARAMASCHI, E. P., 1989, Comportamento alimentar de duas espécies de Curimata, sintópicas no Pantanal de Mato Grosso (Osteichthyes, Characiformes). Rev. Brasil. Biol., 49: 325-333.

SAZIMA, I. \& MACHADO, F. A., 1990, Underwater observations of piranhas in western Brazil. Env. Biol. Fish, 28: 17-31.

SILVA, C. P. da, 1982, Ocorrência, distribuição e abundância de peixes na região estuarina de Tramandaí, Rio Grande do Sul. Atlântica, Rio Grande, 5: 49-66.

TEIXEIRA, R. L., 1989, Aspectos da ecologia de alguns peixes do arroio Bom Jardim, Triunfo, RS. Rev. Brasil. Biol., 49: 183-192.

UIEDA, V. S., 1984, Ocorrência e distribuição dos peixes em um riacho de água doce. Rev. Brasil. Biol., 44: $203-213$

UIEDA, V. S. \& CASTRO, R. M. C., 1999, Coleta e fixação de peixes de riachos. pp. 01-22. In: E. P. Caramaschi, R. Mazzoni \& P. R. Peres-Neto (eds.), Ecologia de peixes de riachos. Série Oecologia Brasiliensis, vol. VI, PPGE-UFRJ, Rio de Janeiro, Brasil.

VIANNA, M., 1989, Ritmo circadiano na atividade, alimentação e partilha de recursos entre peixes de um rio litorâneo da região de Angra dos Reis, RJ. Undergraduate Thesis, Universidade Federal do Rio de Janeiro, Rio de Janeiro, Brazil, 88p.

WELCOMME, R. L., 1979, Fisheries ecology of floodplain rivers. Longman, London \& New York, 317p. 